\title{
Immunodiffusion studies on synovial fluid from patients with rheumatoid arthritis: the reaction of fibrinogen with a streptococcal extract
}

\author{
H. J. RYLANCE \\ From the Rheumatic Diseases Unit, Northern General Hospital, Ferry Road, Edinburgh EH5 2DQ
}

SUMMARY Synovial fluids $(83.3 \%$ ) from patients with rheumatoid arthritis gave a positive reaction when examined by immunodiffusion against a Lancefield extract of Group A Type 12 streptococci. None of the patients with osteoarthrosis reacted positively. An antiserum was prepared to the material in synovial fluid reacting with the streptococcal extract. This antiserum reacted positively with all synovial fluids tested including the osteoarthrosis patients. It also reacted with all plasma samples tested but only with a few $(18.2 \%)$ of serum samples. Immunodiffusion and absorption experiments demonstrated that the material reacting with the streptococcal extract was fibrinogen. Of 12 other streptococci examined only one, a Group $\mathrm{C}$ organism, gave a similar positive reaction with synovial fluids.

Braun and Holm (1970) extending observations on the presence of streptococcal antibodies in human sera from rheumatic fever patients, showed that sera from patients with 'rheumatic arthritis' contained antibodies to cellular antigens of Group A Type 12 streptococci. These patients had sensitised sheep cell agglutination titres between 1:160 and $1: 5120$ as measured by the method of Rose et al. (1948) and hence presumably correspond to patients with clinical rheumatoid arthritis. An examination of synovial fluids from patients with rheumatoid arthritis (RA) for the presence of antibody to Group A streptococci seemed to be of interest in the light of these results.

\section{Materials and methods}

\section{SYNOVIAL FLUID}

Fluid was obtained from patients with, (a) classical or definite rheumatoid arthritis (ARA criteria), (b) uncomplicated osteoarthrosis (OA), and, (c) other connective tissue disease.

Fluids were treated with hyaluronidase (B.D.H., $0.1 \mathrm{mg} / \mathrm{ml}$ ) at $37^{\circ} \mathrm{C}$ overnight and then centrifuged. The supernatant was submitted to immunodiffusion. All the fluids used were free from blood, as judged by eye.

Accepted for publication October 27, 1977

\section{ANTIGEN PREPARATIONS}

A Lancefield acidic extract was prepared from a nephritogenic streptococcal strain, Group A Type 12, by the method given by Cruickshank (1965). This was used in most of the experiments. In certain experiments corresponding extracts from other Group A streptococci and streptococci of Groups $\mathbf{B}, \mathbf{C}, \mathbf{D}$, and $\mathbf{G}$ were prepared in a similar manner. The streptococci were supplied by $\mathrm{Mr}$ W. Marr, Department of Bacteriology, University of Edinburgh.

Four strains of diphtheroid organisms isolated from the synovial fluid of rheumatoid arthritis patients (Stewart et al., 1969) were similarly extracted with acid. These organisms were supplied by Dr S. M. Stewart, Department of Bacteriology, University of Edinburgh.

Streptococcal (Group A Type 12) polysaccharidemucopeptide complex prepared from purified cell walls was a gift from Dr Heymann and Ms Manniello of Ciba-Geigy.

\section{IMMUNODIFFUSION}

Immunodiffusion was carried out as described by Clausen (1969) using $3 \mathrm{ml}$ of a $1 \%$ agar gel in $0.05 \mathrm{M}$ barbitone buffer $(\mathrm{pH} \mathrm{8.4)}$ on $5 \times 5 \mathrm{~cm}$ glass slides. Diffusion was carried out in a moist atmosphere at room temperature $\left(20^{\circ} \mathrm{C}\right)$. Fluids were tested, without dilution, against the antigen preparations. 
A commercial antiserum (Wellcome Reagents Limited) against Group A streptococci was used to test each new batch of Group A Type 12 streptococcal extract; this gave a strong precipitin line against the antigen extract. Some gels were prepared containing $1 \%(\mathrm{w} / \mathrm{v}) \mathrm{N}$-acetylglucosamine.

\section{IMMUNOELECTROPHORESIS}

This was carried out in $1 \%$ agar gels in $0.05 \mathrm{M}$ barbitone buffer (pH 8.4). Electrophoresis was carried out using a Shandon electrophoresis tank and power pack: $0.05 \mathrm{M}$ barbitone buffer $(\mathrm{pH}$ 8.4): a voltage of $6-7 \mathrm{~V} / \mathrm{cm}$ measured across the wicks, and a time of $90 \mathrm{~min}$. Diffusion afterwards was at room temperature overnight.

\section{ABSORPTION \\ Absorption of fluids and antisera was carried out as described by Clausen (1969). Antigen solution was added to the fluids in the proportion of $1: 1,2: 1$, $4: 1$, and $8: 1$, mixed and incubated at $37^{\circ} \mathrm{C}$ for $30 \mathrm{~min}$. The solutions were tested after centrifuga- tion.}

\section{PREPARATION OF ANTISERUM}

A synovial fluid strongly positive to a Group A Type 12 streptococcal acidic extract was treated with sufficient of this preparation to precipitate the reacting material. The precipitate was washed once with cold saline.

The preparation of an antiserum to this material was arranged by Dr J. N. McCormick. The material was emulsified with Freund's adjuvant and injected into rabbits. A booster dose was given 4 weeks later. The antiserum was absorbed with pooled normal human serum until, when tested by immunodiffusion and immunoelectrophoresis, only one line was obtained with an RA synovial fluid and no line observed with human serum.

\section{Results}

Initially synovial fluids were examined by immunodiffusion against a Lancefield extract of Group A Type 12 streptococci. Tested in this way $83.3 \%$ of synovial fluids from rheumatoid arthritis patients gave a positive precipitin reaction; none of the osteoarthrosis fluids was positive (Table). When sera from a further 19 RA patients were also tested by immunodiffusion, in parallel with corresponding synovial fluids, only 6 of the 19 serum samples reacted positively whereas 14 of the 19 fluids gave a positive result. Four osteoarthrosis cases gave negative results both with serum and synovial fluid. The material reacting with the streptococcal antigen, therefore, seemed to be mainly in the synovial fluid of patients with rheumatoid arthritis.
Table The incidence of positive immunodiffusion results in three groups of patients

\begin{tabular}{|c|c|c|c|}
\hline & Osteoarthrosis & $\begin{array}{l}\text { Rheumatoid } \\
\text { arthritis }\end{array}$ & $\begin{array}{l}\text { Other } \\
\text { inflammatory } \\
\text { conditions* }\end{array}$ \\
\hline $\begin{array}{l}\text { No. of patients } \\
\text { No.giving } \\
\text { positive precipitin } \\
\text { bands }\end{array}$ & 15 & 54 & 17 \\
\hline
\end{tabular}

ankylosing spondylitis, and 8 patients with 'synovitis'.

When an antiserum to the reacting material in RA synovial fluid was available the samples were retested using this. All synovial fluids, including those from osteoarthrosis patients, gave a positive precipitin reaction. Only a few $(18.2 \%)$ of the serun samples reacted positively.

When plasma samples were teated instead of serum the results were quite different and, in facto all plasma samples gave positive reactions including. samples from controls. It seemed possible, therefore that fibrinogen was the material reacting with the streptococcal antigen extract.

This was confirmed by immunodiffusion and immunoelectrophoresis. Fibrinogen $(2 \% \mathrm{Kabi})$ ggve a clear precipitin line with the Group A Typegl $2^{\circ}$ streptococcal extract. In order to obtain a phefo graphic record (Fig. 1) of the fusion of this arc that between a synovial fluid and the streptococca extract it was necessary to concentrate the streptoo coccal extract and the synovial fluid to about hat volume. Fig. 2 shows the reactions of the antiserun to the synovial fluid component with synovial flui and with fibrinogen. Fusion of the arcs agaip occurred. The reactions of identity with a commercia anti-fibrinogen serum (Hoechst Pharmaceuticalsst and the antiserum to the synovial fluid componen against a synovial fluid are shown in Fig. 3 and against fibrinogen in Fig. 4. Immunoelectrophores of synovial fluid confirmed that the reacting materia had the characteristics of fibrinogen.

Absorption experiments further confirmed the identification: (1) fibrinogen added to the antiserum against the synovial fluid component removed the. appropriate antibody, (2) addition of fibrinogen to the streptococcal antigen extract removed the material reacting with synovial fluid, and (3) afteo addition of sufficient fibrinogen antiserum to synovial fluid the synovial fluid no longer reacte with the streptococcal extract nor the antiserum prepared against the synovial fluid componen Controls for all experiments were carried out in parallel adding saline. Fibrinogen (and/or some of its degradation products) was obviously the reactie material in the synovial fluids. 


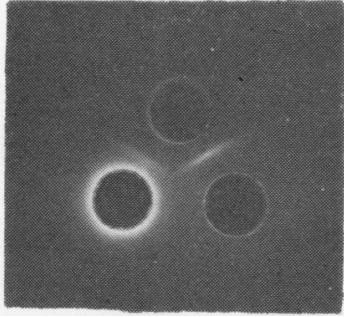

Fig. 1

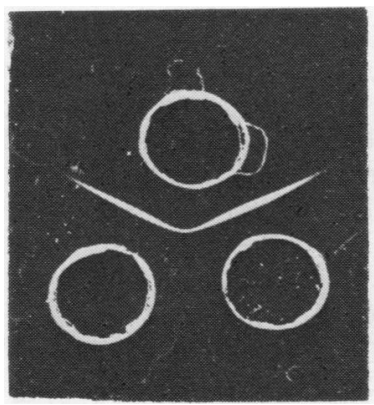

Fig. 2

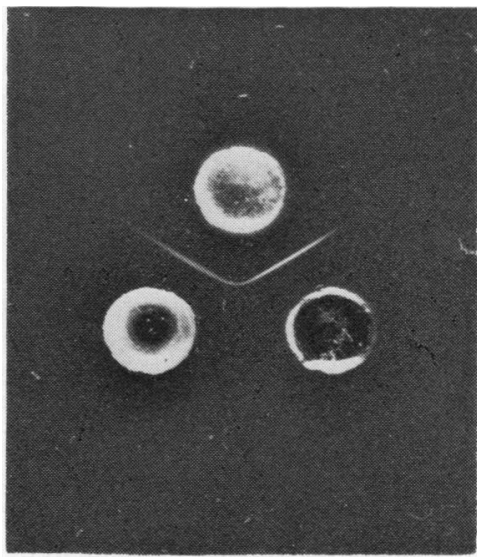

Fig. 3

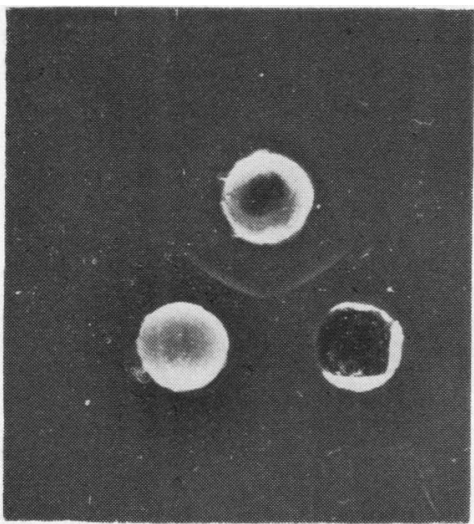

Fig. 4
Photographs of immunodiffusion gels showing fusion of precipitin arcs between:

Fig. 1 Streptococcal extract (top well) and fibrinogen (bottom left well) and a synovial fluid (bottom right well).

Fig. 2 Antiserum to synovial fluid component (top) and synovial fluid (bottom left) and fibrinogen (bottom right).

Fig. 3 Synovial fluid (top) and the antiserum to the synovial fluid component (bottom left) and a fibrinogen antiserum (bottom right).

Fig. 4 Fibrinogen (top) and the antiserum to the synovial fluid component (bottom left) and a fibrinogen antiserum (bottom right).
Fibrinogen was treated with streptokinase (as varidase): with $10 \mathrm{~min}$ treatment at $37^{\circ} \mathrm{C}$ the reaction with the streptococcal extract was still retained. Treatment for $60 \mathrm{~min}$ or longer destroyed the reactivity to the streptococcal extract, although the antiserum (to the synovial fluid) still reacted positively as did the anti-fibrinogen antiserum.

The addition of streptococcal antigen extract to the antiserum raised in rabbits did not remove the antibody to fibrinogen and in fact the antiserum only rarely showed a very faint and doubtful positive precipitin band with the streptococcal extract. The antibody was obviously mainly, if not entirely, directed against the fibrinogen part of the streptococcal antigen-fibrinogen complex.

The material in the streptococcal extract reacting with fibrinogen was further studied. Immunodiffusion showed that it was not the same as that which reacted with the commercial anti Group A streptococcal serum (Wellcome). Also when cell wall mucopeptide was tested, at levels from $5 \mu \mathrm{g} / \mathrm{ml}$ to $20 \mathrm{mg} / \mathrm{ml}$ against several fluids which reacted against the streptococcal extract, no positive reaction was obtained with any fluid and the presence of $\mathrm{N}$ acetyl glucosamine in the agar gel did not inhibit the formation of precipitin lines. $\mathrm{N}$-acetyl glucosamine
( $1 \%$ ) inhibits the raction between the Group specific polysaccharide and the corresponding antibody (Braun and Holm, 1970).

The acidic extracts of other streptococci gave no precipitin bands when tested against synovial fluids with the exception of one Group C organism which had been isolated from a mid-stream urine specimen (Royal Infirmary, Edinburgh). The organisms tested were 2 other Group A, 4 Group B, 4 Group C, 1 Group D, and 1 Group G streptococci.

No reaction was obtained with any of the diphtheroid organisms and synovial fluids.

\section{Discussion}

Braun and Holm (1970) detected antibodies to Group A streptococci in $66 \%$ of the sera examined from rheumatoid arthritis patients and in only $6 \%$ of a control group. With synovial fluids we found that $86.3 \%$ of RA patients reacted positively to a Lancefield extract of Group A streptococci and in that respect our results appeared to agree with those of Braun and Holm (1970) using serum samples. However, the reactive species in the Lancefield extract is not the Group A specificpoly saccharide and the component in the synovial fluid involved in the 
immunodiffusion reaction appears to be fibrinogen (or a closely related molecule). There may, of course, be antibodies to Group A specific carbohydrate in the serum and it is noticeable that $31.6 \%$ of the RA serum samples reacted positively to the Lancefield streptococcal extract but only $18.2 \%$ of these samples reacted with the much more sensitive antiserum.

The material in the Lancefield extract is not the same as that which reacts with the streptococcal Group A antiserum; a conclusion confirmed by the lack of reaction of Group A cell-wall polysaccharidemucopeptide complex with synovial fluids. The fact that other Group A streptococci tested did not react with synovial fluids suggests the possibility that the reacting material may be the type specific $M$ protein. This material is extractable in acid along with the Group polysaccharide (Cruickshank, 1965).

The component in the synovial fluid which reacted with the streptococcal extract appeared to be fibrinogen and/or possibly the material detected by Schur and Sandson (1963) and designated $\beta 2 F$. Beta $2 F$ is produced from fibrinogen by treatment with streptokinase for $10 \mathrm{~min}$; fibrinogen specimens treated in this way still retained activity.

Attempts to implicate streptococci in rheumatoid arthritis have been made in the past but the nonspecificity of the results have usually been acknowledged in the end (see Gardner, 1972). The observation that fibrinogen can give a sharp precipitin band in immunodiffusion experiments with streptococcal extracts also indicates another source of confusion in attempts to implicate streptococci in the aetiology of rheumatoid arthritis.

It is, however, of interest that, of the streptococci tested, only the Group A Type 12 and a Group C organism gave extracts which reacted positively against synovial fluids and fibrinogen. Whether this indicates that a suitable $\mathrm{M}$-protein could react with fibrinogen in vivo and initiate some adverse reaction remains to be studied. Certainly, in that case, one might expect to find evidence for a $\mathbf{M}$-protein or a fibrinogen-M-protein complex in RA synovial fluids and not in fluids from OA patients.

Barnhart et al. (1971) have suggested that fibrinogen, fibrin, and their proteolysis products may play a part in the inflammatory process, and they showed that fibrinogen-derived polypeptides increased vascular permeability in rabbits and guinea pigs. Fibrinogen has also been shown to be present in increased amounts in inflammatory synovial fluids (Takeda, 1967) and has been used as an indicator of the degree of inflammation. Fibrinogen may, therefore, have some fundamental role in the inflammatory process and any alteration, for example by combination with a streptococcal component, could be of major importance.
A final speculation is that the fibrinogenstreptococcal M-protein could be treated by the body as a foreign protein and, in this way, be the stimulus for the inflammatory reaction. Various $\Rightarrow$ substances, including streptococci (Stein et al., 1973 ; Svartz, 1976), and proteins (Consden et al., 1971)o have been shown to cause an inflammatory reactiono in the joint in experimental animals.

During the course of this work the Rheumatic Unito was supported by a grant from the Arthritis and Rheumatism Council. I should like to thank the:Medical Photography Department, Western General $\vec{\omega}$ Hospital, Edinburgh and Mrs R. C. Wallace for the photographs and Mrs E. Neil for secretaria $\frac{\tilde{L}_{2}}{2}$ assistance.

\section{References}

Barnhart, Marion I., Sulisz, L., and Bluhm, G. B. (1971) Role for fibrinogen and its derivatives in acute inflammation. In Immunopathology of Inflammation. Ed. by B. K. Forester and J. C. Houck, pp. 59-65. Excerpt程 Medica, Amsterdam.

Braun, D. G., and Holm, S. E. (1970). Streptococcal antigroup A precipitins in sera from patients with rheumatice arthritis and acute glomerulonephritis. Internatiomabo Archives of Allergy and Applied Immunology, 37, 216-224

Clausen, J. (1969). Immunological Techniques for Identification and Estimation of Macromolecules, pp. $5 \nsupseteq \mathrm{S}$ 516, and 522. North-Holland, Amsterdam and London:

Consden, R., Doble, A., Glynn, L. E., and Nind, A. (1971) The Production of a Chronic Arthritis with Ovalbumin and its Retention in the Rabbit Knee Joint. VII European Rheumatology Congress, Brighton (Abstract-34.8).

Cruickshank, R., Ed. (1965) Medical Microbiology. 11 th ed. p. 159. Livingstone, Edinburgh.

Gardner, D. L. (1972). The Pathology of Rheumatoid Arthritis p. 100. Fdward Arnold Ltd., London.

Rose, H. M. Ragan, C., Pearce, E., and Lipman, M. Od (1948). Differential agglutination of normal and sensitiseç sheep erythrocytes by sera of patients with rheumatoid arthritis. Proceedings of the Society for Experimenta?. Biology and Medicine, 68, 1-6.

Schur, P. H., and Sandson, J. (1963). Immunologic studies of the proteins of human synovial fluid. Arthritis and Rheumatism, 6, 115-129.

Stein, H., Yarom, R., Levin, S., Dishon, T., and Ginsburg, I.D (1973). Chronic self-perpetuating arthritis induced ir? rabbits by a cell-free extract of Group A streptococci Proceedings of the Society for Experimental Biology and Medicine, 143, 1106-1112.

Stewart, S. M., Alexander, W. R. M., and Duthie, J. J. RO (1969). Isolation of diphtheroid bacilli from synoviaf membranes and fluid in rheumatoid arthritis. Annals of the Rheumatic Diseases, 28, 477-487.

Svartz, N. (1976). Comparison between the signs of inflame mation in human rheumatoid arthritis and in experimenta雨 arthritis, provoked by streptococci Group B in animals Agents and Action, 6, 287.

Takeda, Y. (1967). Studies of the metabolism and distribution of fibrinogen in patients with rheumatoid arthritis. Journa of Laboratory and Clinical Medicine, 69, 624-633 